\title{
Biochar Tablets with and without Embedded Fertilizer on the Soil Chemical Characteristics and Nutrient Use Efficiency of Zea mays
}

\author{
Yit Leng Lee ${ }^{1,2, *}$, Osumanu Haruna Ahmed ${ }^{2,3,4}$, Samsuri Abdul Wahid ${ }^{5}$ and Zakry Fitri AB Aziz ${ }^{2}$ (D) \\ 1 Faculty of Mechanical Engineering Technology, Kampus Alam UniMAP Pauh Putra, \\ Universiti Malaysia Perlis, Arau 02600, Perlis, Malaysia \\ 2 Department of Crop Science, Faculty of Agriculture and Food Sciences, Universiti Putra Malaysia Bintulu \\ Campus, Bintulu 97008, Sarawak, Malaysia; osumanu@upm.edu.my (O.H.A.); \\ zakryfitri@upm.edu.my (Z.F.A.A.) \\ 3 Institut Ekosains Borneo, Universiti Putra Malaysia Bintulu Campus, Bintulu 97008, Sarawak, Malaysia \\ 4 Institute of Tropical Agriculture and Food Security, Universiti Putra Malaysia, \\ Serdang 43400, Selangor, Malaysia \\ 5 Department of Land Management, Faculty of Agriculture, Universiti Putra Malaysia, \\ Serdang 43400, Selangor, Malaysia; samsuriaw@upm.edu.my \\ * Correspondence: yllee@unimap.edu.my
}

check for updates

Citation: Lee, Y.L.; Ahmed, O.H.; Wahid, S.A.; AB Aziz, Z.F. Biochar Tablets with and without Embedded Fertilizer on the Soil Chemical Characteristics and Nutrient Use Efficiency of Zea mays. Sustainability 2021, 13, 4878. https://doi.org/ $10.3390 /$ su13094878

Academic Editor: António Dinis Ferreira

Received: 4 March 2021

Accepted: 6 April 2021

Published: 27 April 2021

Publisher's Note: MDPI stays neutral with regard to jurisdictional claims in published maps and institutional affiliations.

Copyright: (c) 2021 by the authors. Licensee MDPI, Basel, Switzerland. This article is an open access article distributed under the terms and conditions of the Creative Commons Attribution (CC BY) license (https:// creativecommons.org/licenses/by/ $4.0 /)$.

\begin{abstract}
Densification of ashy biochar into tablet can enhance the handling and conveyance efficiencies of biochar. It was hypothesized that fertilizer-embedded biochar tablets can slowly release embedded nutrients in synchrony with optimum nutrient uptake by crops. The objectives of this research were to determine the effects of biochar tablets with and without embedded fertilizer on soil chemical properties and nutrient use efficiency of Zea mays (sweet corn). The biochar tablet (BT) was produced by blending a biochar mixture with starch followed by densification using a single punch tablet press whereas the fertilizer embedded biochar tablet (BF) was prepared using the same procedure except that NPK fertilizer was added during blending. A pot experiment with five fertilization treatments including control was carried out in an open field located in Perlis, Malaysia. Co-application of biochar and fertilizer increased soil total carbon, nitrogen, but it reduced soil electrical conductivity (EC). Additionally, the BF significantly increased leaf chlorophyll content, dry root weight, and total plant nutrient use efficiency of sweet corn. The findings suggest that BF can serve as a slow release fertilizer to improve crop nutrient use efficiency. Therefore, embedding fertilizer in biochar tablets is recommended for sweet corn production following a long term field study to confirm the findings of this pot study.
\end{abstract}

Keywords: rice residues; densification; leaf chlorophyll content; ammonium; slow release nutrient

\section{Introduction}

Mineral fertilizers are major farming inputs that are used to increase crop productivity worldwide. In Malaysia, approximately 3.72 million metric tons of fertilizer was produced in 2019 [1]. Although mineral fertilizers use promptly ameliorates nutrient deficiencies in soils or plants, extensive use of chemical fertilizers in particular adversely impact the environment and crop productivity negatively. An alternative approach such as coapplication of fertilizer and organic material is considered as a sustainable method for soil nutrient improvement. Oladele et al. [2] reported improvement of plant growth following co-application of biochar and fertilizers although crop yield reduction with co-application of biochar and mineral fertilizer has been reported $[3,4]$. These contracting findings could be associated with the fact that the effects of biochar on plant growth and development depend on biochar type, biochar production process, and biochar application rate. 
Biochar has gained attention because it is widely used as soil amendment, absorbent, and energy production [5]. The quality of biochar varies with pyrolysis temperature and the type of raw materials used [6,7]. Biochar application to soils has been reported to increase nutrient retention which translates into improved the nutrient use efficiency [8]. Soil nitrogen $(\mathrm{N})$ in the forms of ammonium $\left(\mathrm{NH}_{4}{ }^{+}\right)$and nitrate $\left(\mathrm{NO}_{3}{ }^{-}\right)$are commonly leached from soils into groundwater following intensive rainfall or irrigation. This process of losing $\mathrm{N}$ contaminates ground water and other water bodies to cause eutrophication. Sun et al. [9] reported that biochar application reduced $\mathrm{N}$ leaching by 23.1 to $32.4 \%$. However, reports on the effects of biochar application on the leaching of soil inorganic $\mathrm{N}$ are inconsistent. Teutscherova et al. [10] reported that $\mathrm{NH}_{4}{ }^{+}$leaching was increased by higher biochar application rate without fertilization, but the loss of $\mathrm{NH}_{4}{ }^{+}$decreased by the lower biochar application rate with addition of fertilizer.

Although application of biochar could reduce nutrient leaching, the density of biochar is low and for example, approximately 30\% of biochar are wind-blown during handling and application to soil [11]. Biochar is an ashy material to work with, but densification of biochar could reduce this undesirable property. Fertilizer-embedded biochar pellets can hold nutrients for a long time because of their smaller pore sizes and reduced total pore volume after densification [12]. A recent study demonstrated that adding fertilizer embedded biochar tablet to soil could increase the soil total nitrogen and cation exchange capacity as well [13]. This indicates that the combination of biochar and fertilizer following densification is more efficient to minimize the losses of nutrients in soil and hence improve the plant nutrient use efficiency. Nevertheless, there is lack of knowledge on the nutrient use efficiency of plants which are cultivated on soils that are amended with fertilizer embedded biochar tablets. The objective of this study was to determine the effects of biochar tablets with and without embedded fertilizer on the soil chemical properties and nutrient use efficiency of sweet corn. Therefore, we hypothesized that adoption of biochar tablet embedded with fertilizer in farming systems could simultaneously reduce nutrient loss and adverse effect of mineral salts concentration of the chemical fertilizers on plants to ensure significant improvement in nutrient use efficiency and productivity of plants.

\section{Materials and Methods}

\subsection{Samples Collection and Preparation}

The rice straw, rice husk, and rubber tree twigs used in this present study were procured from a paddy field $\left(6.445558^{\circ} \mathrm{N}, 100.318728^{\circ} \mathrm{E}\right)$ and a rubber tree plantation $\left(6.521817^{\circ} \mathrm{N}, 100.309526^{\circ} \mathrm{E}\right)$ in Perlis, northern Malaysia. The samples were sun-dried for 3 days after which the rubber tree twigs were cut into $2 \mathrm{~cm}$ using a wood chipper (RC61605, SIMA, Shandong, China) whereas the rice straw was cut into $15 \mathrm{~cm}$ size. The rubber tree twigs, rice straw, and rice husks were charred separately before the production of the biochar tablets with and without embedded fertilizer. Figure 1 shows a diagram of the study workflow.

\subsection{Biochar Production and Preparation}

Biochar was produced using a stainless steel kiln fabricated locally at the Faculty of Mechanical Engineering Technology, Universiti Malaysia Perlis, Perlis, Malaysia. The temperature was measured using an infrared thermometer (TM969, Lutron, Taipei, Taiwan) at $30 \mathrm{~min}$ interval (during the combustion). During charring, a maximum temperature of $500{ }^{\circ} \mathrm{C}$ was attained after one hour of ignition. Throughout the charring process, the average temperature of the kiln was approximately $340^{\circ} \mathrm{C}$. The charring process was completed in $2 \mathrm{~h}$ after which the charred product was collected and weighed to determine the percentage yield of the charring process. The percentage yield of the char was approximately $34 \%$. The charred materials were ground and sieved to pass a $1 \mathrm{~mm}$ sieve before the biochar tablets were produced. 


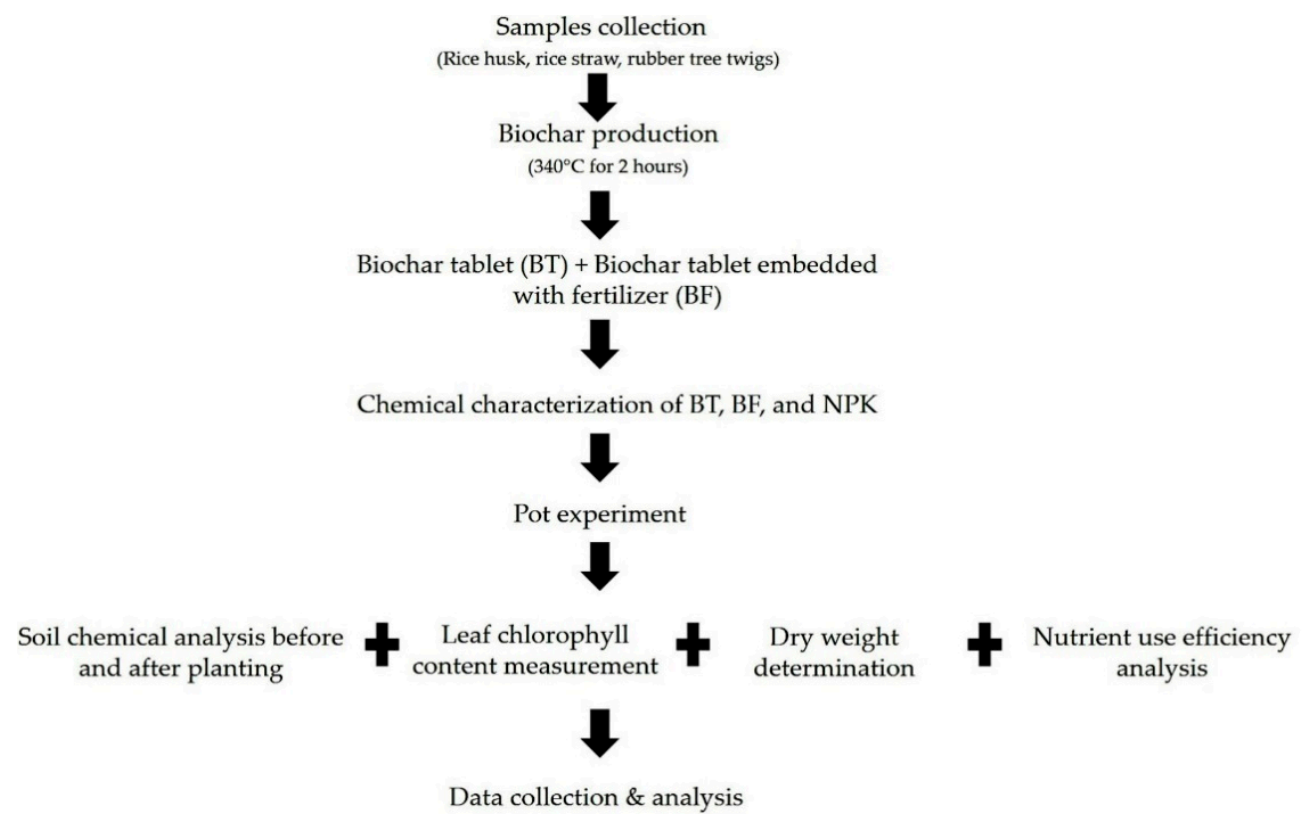

Figure 1. Workflow diagram of the study.

\subsection{Biochar Tablet (BT) and Biochar Tablet Embedded with Fertilizer (BF) Production}

The biochar tablet (BT) was prepared by blending a mixture of charred rice husk, charred rice straw, and charred rubber twigs at a ratio of 5:3:2, respectively with starch (20\% by wt.), and water (30\% by wt.) using a mixer. The ratio 5:3:2 used for blending a mixture of charred rice husk, charred rice straw, and charred rubber twigs into a tablet was based on the availability of the materials. Thereafter, the mixture was heated at $100{ }^{\circ} \mathrm{C}$ for $5 \mathrm{~min}$ using a water bath (MaXturdy ${ }^{\mathrm{TM}}$ 30, Daihan, Seoul, Korea) followed by a densification step using single press tablets (MTB3, Micro-Tec, East Sussex, England) with a punch weight of 0.4 tons. Tablets which were $6 \mathrm{~mm}$ in height and $10 \mathrm{~mm}$ in diameter were produced. The BT was oven dried at $60{ }^{\circ} \mathrm{C}$ for one hour after which it cooled and kept in an air-tight container. The same procedure was used to produce the biochar tablet embedded fertilizer (BF) except that NPK fertilizer (5:3:3) was added to the mixture after water bath heating at $100{ }^{\circ} \mathrm{C}$ for five minutes. The biochar to fertilizer ratio was 2:1. The pictures of BT, BF, and NPK were displayed in Figure 2.

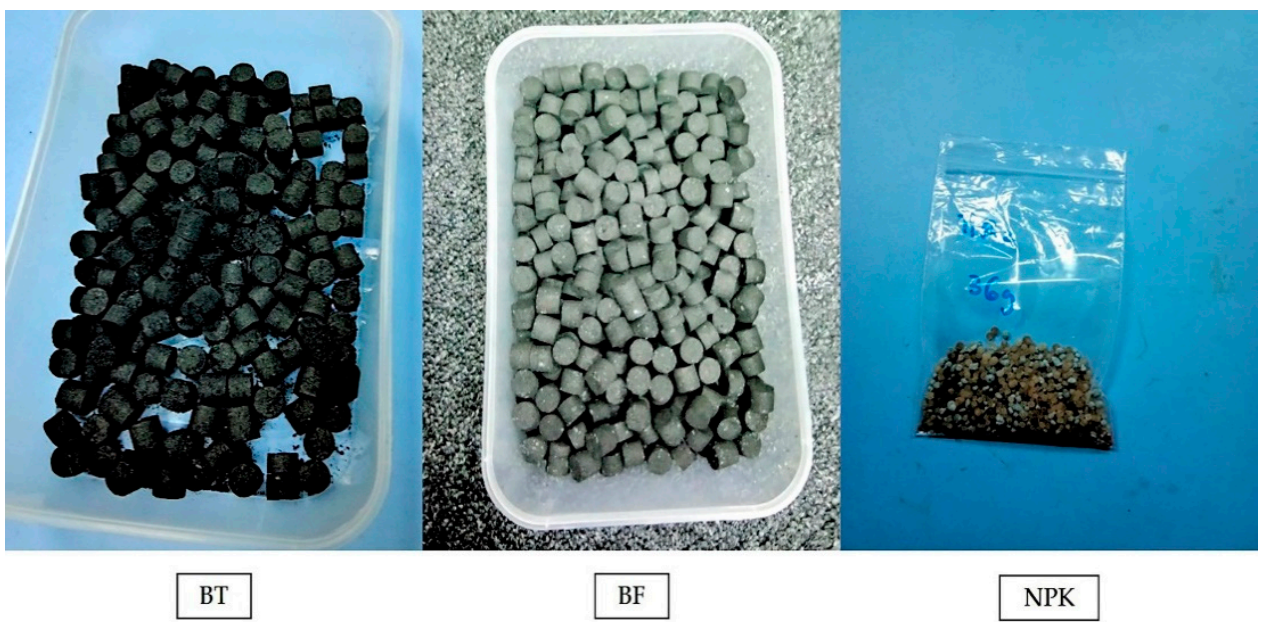

Figure 2. Images of biochar tablet (BT), biochar tablet embedded with fertilizer (BF), and NPK. 


\subsection{Chemical Characterization of Biochar Tablet (BT), Biochar Tablet Embedded with Fertilizer (BF), and NPK Fertilizer}

The $\mathrm{pH}$ and electrical conductivity (EC) of BT, BF, and NPK were determined using a pH meter (PB10, Sartorius, Taguig, Philippines) and a conductivity meter (EC3000, STEP Systems GmbH, Nurnberg, Germany) respectively. Total carbon (TC) and total nitrogen (TN) of BT and BF were determined using a CNS analyzer (TruSpec, LECO Corporation, St. Joseph, MI, USA) while the dry ashing method was adopted for the content determination of phosphorus $(\mathrm{P})$, potassium $(\mathrm{K})$ for BT and BF. The NPK fertilizer was sent for total nitrogen, phosphorus and potassium content determination based on the AOAC Official Method 955.04, 958.01, and 965.09. Data for selected chemical properties of BT, BF, and NPK fertilizer was presented in Table 1.

Table 1. Selected chemical properties of biochar tablets (BT), fertilizer embedded in biochar tablet (BF) and NPK fertilizer.

\begin{tabular}{cccc}
\hline Chemical Properties & BT & BF & NPK \\
\hline $\mathrm{pH}$ & $9.34 \pm 0.01$ & $5.92 \pm 0.02$ & $3.35 \pm 0.04$ \\
Electrical conductivity $\left(\mathrm{mS} \mathrm{cm}^{-1}\right)$ & $3.78 \pm 0.04$ & $41.16 \pm 0.76$ & $90.9 \pm 0.90$ \\
Total carbon (\%) & $48.49 \pm 0.12$ & $32.35 \pm 0.42$ & n.a \\
Total nitrogen (\%) & $0.75 \pm 0.01$ & $4.96 \pm 0.11$ & $13.73 \pm 0.27$ \\
Total phosphorus (\%) & $0.07 \pm 0.01$ & $0.36 \pm 0.01$ & $4.40 \pm 0.10$ \\
Total potassium (\%) & $1.23 \pm 0.09$ & $2.45 \pm 0.06$ & $8.28 \pm 0.23$ \\
\hline
\end{tabular}

Values are means of three replicates followed by \pm standard error of means $(n=3)$.

\subsection{Pot Experiment}

A pot study was conducted in an open field located at Arau, Perlis, Malaysia $\left(6.446950^{\circ} \mathrm{N}\right.$, $100.321475^{\circ} \mathrm{E}$ ). Plastic pots measuring $32 \mathrm{~cm}$ (height) $\times 28 \mathrm{~cm}$ (diameter) were used and each pot was filled with $9.6 \mathrm{~kg}$ air-dried soil. The soil chemical properties were also determined before planting (Table 2). Rainfall data was collected using a rain gauge and the precipitation from April to May 2018 (53 days after planting) was approximately $469 \mathrm{~mm}$.

Table 2. Selected chemical properties of soil before planting sweet corn.

\begin{tabular}{cc}
\hline Chemical Properties & Soil \\
\hline $\mathrm{pH}$ & $5.66 \pm 0.03$ \\
Electrical conductivity $\left(\mathrm{mS} \mathrm{cm}^{-1}\right)$ & $0.05 \pm 0.01$ \\
Total carbon $\left(\mathrm{g} \mathrm{kg}^{-1}\right)$ & $7.47 \pm 0.33$ \\
Total nitrogen $\left(\mathrm{g} \mathrm{kg}^{-1}\right)$ & $1.00 \pm 0.06$ \\
Available P $\left(\mathrm{mg} \mathrm{kg}^{-1}\right)$ & $0.25 \pm 0.03$ \\
Exchangeable K $\left.\left(\mathrm{cmol}^{-1}\right) \mathrm{kg}^{-1}\right)$ & $0.12 \pm 0.02$ \\
Exchangeable Ca $\left.\left(\mathrm{cmol}^{-1}\right) \mathrm{kg}^{-1}\right)$ & $6.82 \pm 0.40$ \\
Exchangeable Mg $\left.\left(\mathrm{cmol}^{-1}\right) \mathrm{kg}^{-1}\right)$ & $1.53 \pm 0.45$ \\
CEC $\left(\mathrm{cmol}(+) \mathrm{kg}^{-1}\right)$ & $10.52 \pm 0.42$ \\
\hline Values are means of three replicates followed by \pm standard error of means $(\mathrm{n}=3)$.
\end{tabular}

There were 5 fertilization treatments including a control. The experiment was conducted using a completely randomized design with 5 replications. A mineral clay soil (Malacca series, Oxisol) was used in the experiment. The test crop used in this present study was F1 hybrid sweet corn variety 516. The crops were irrigated with tap water and the soil moisture was maintained at $60 \%$ field capacity. The amounts of ammonium sulfate (AS), triple superphosphate (TSP), and muriate of potash (MOP) used were based on the rates recommended by the Department of Agriculture, Malaysia. The rates used in this study were a scale down of the standard fertilizer recommendation for the test crop. Treatment T3 was based on the standard recommendation of biochar and fertilizer for the test crop. The application rates of fertilizer were reduced in T4 and the application rate for T5 was a proportion of biochar to fertilizer in 2:1 ratio. The proportionate treatments 
$\mathrm{T} 3, \mathrm{~T} 4$, and $\mathrm{T} 5$ were varied to determine the best co-application rate for improving the plant nutrient use efficiency and soil quality. The amounts of AS, TSP, and MOP used were $90 \mathrm{~kg} \mathrm{ha}^{-1} \mathrm{~N}, 60 \mathrm{~kg} \mathrm{ha}^{-1} \mathrm{P}_{2} \mathrm{O}_{5}$, and $60 \mathrm{~kg} \mathrm{ha}^{-1} \mathrm{~K}_{2} \mathrm{O}$, respectively. The fertilizer application was scaled down to per pot basis as follows:

i. $\quad$ T1: soil only (control);

ii. $\quad$ T2: $36 \mathrm{~g}$ of mixture of NPK fertilizer;

iii. $\quad$ T3: $67 \mathrm{~g}$ ( $36 \mathrm{~g}$ of mixture NPK fertilizer $+31 \mathrm{~g}$ biochar tablet);

iv. $\quad$ T4: $67 \mathrm{~g}(29 \mathrm{~g}$ of mixture NPK fertilizer $+38 \mathrm{~g}$ biochar tablet);

v. T5: $67 \mathrm{~g}$ of biochar tablet embedded fertilizer with 2:1 ratio (23 $\mathrm{g}$ of NPK embedded $44 \mathrm{~g}$ of biochar tablet).

The fertilizers were surface applied at 10 and 27 days after planting (DAP). The sweet corn plants were grown for 53 days after planting (tasseling stage) because this growth stage is the maximum sweet corn plant growth stage before their reproductive stage. Before harvesting, the chlorophyll contents of the sweet corn plants were measured using a SPAD chlorophyll meter (SPAD-502, Konica Minolta, Osaka, Japan). At tasseling (53 days after planting), the sweet corn plants were harvested and partitioned into leaves, stems, roots, and flowers. Thereafter, they were cleaned, and oven-dried at $60^{\circ} \mathrm{C}$ until constant weight was attained. Afterwards, the dry weight of the leaves, stems, roots, and flowers weight were determined using a digital weighing machine (UWA-C015, Accutec, Taipei, Taiwan). In addition, at 53 DAP, soil samples were taken from $0-15 \mathrm{~cm}$ depth of the pots (immediately after harvesting the sweet corn plants) and air-dried, ground and sieved less than $2 \mathrm{~mm}$ for chemical analysis. $\mathrm{pH}$ and electrical conductivity (EC) of the soil were determined using a pH meter (PB10, Sartorius, Taguig, Philippines) and a conductivity meter (EC3000, STEP Systems GmbH, Nurnberg, Germany), respectively. The soil and water ratio for the determination of $\mathrm{pH}$ and $\mathrm{EC}$ was $1: 5(\mathrm{v} / \mathrm{v})$. Ammonium acetate $\left(\mathrm{NH}_{4} \mathrm{OAc}\right)$ shaking method [14] was used to determine the exchangeable potassium (K), calcium $(\mathrm{Ca})$, magnesium $(\mathrm{Mg})$, and cation exchange capacity (CEC) of the soil. The extracted ammonium was determined for CEC using an auto-analyzer (QuikChem 8000 Series FIA+ System, Lachat Instruments, Loveland, CO, USA) while the soil exchangeable cations were measured in the $\mathrm{NH}_{4} \mathrm{OAc}$ extract by atomic absorption spectrometry (AAS) (AAnalyst 400; PerkinElmer, Waltham, MA, USA). Bray P-II method was used to extract the soil available phosphorus [15] and the $\mathrm{P}$ in the extract was determined using inductively couple plasma optical emission spectrometer (ICP-OES) (Optima 8300, PerkinElmer, Waltham, MA, USA). Total carbon $(\mathrm{C})$ and $\mathrm{N}$ were determined using the dry combustion method. The analytical machine used for this analysis was a CNS analyzer (TruSpec, LECO Corporation, St. Joseph, MI, USA).

The total $\mathrm{N}$ in sweet corn plants' tissues was determined using the dry combustion method and the analytical machine used for this analysis was a CNS analyzer (TruSpec, LECO Corporation, St. Joseph, MI, USA). Total P and K were extracted using the dry ashing method [16] after which the $\mathrm{P}$ and $\mathrm{K}$ contents in the extract were determined using AAS (AAnalyst 400, PerkinElmer, Waltham, MA, USA). The concentrations of N, P, and K in the plant parts multiplied by their dry weight gave the amount of $\mathrm{N}, \mathrm{P}$, and $\mathrm{K}$ taken up by the plant parts. The fertilizer nutrient use efficiency (NUE) was calculated using the formula of Pomares-Gracia and Pratt [17]:

$$
\% \mathrm{NUE}=\frac{\mathrm{TNF}-\mathrm{TNU}}{\mathrm{RFA}} \times 100,
$$

where,

$\mathrm{TNF}=$ total nutrient uptake of fertilized plants $(\mathrm{g})(\mathrm{T} 2, \mathrm{~T} 3, \mathrm{~T} 4$ and T5),

$\mathrm{TNU}=$ total nutrient uptake of unfertilized plants (g) (T1), and

RFA $=$ rate of fertilizer applied $(\mathrm{g})$. 


\subsection{Statistical Analysis}

Analysis of variance (ANOVA) was used to determine the significant effects of treatments whereas the treatment means were compared using the Tukey's test at $p \leq 0.05$. The Statistical Analysis System (SAS) software version 9.2 was used for the statistical analysis.

\section{Results}

\subsection{Selected Chemical Properties of Soil after Planting Sweet Corn}

The $\mathrm{pH}$ of the soil only (T1) was the highest whereas the lowest $\mathrm{pH}$ was recorded for T5. The soil $\mathrm{pH}$ for T2, T3, and T4 was not significantly different. The highest $\mathrm{EC}$ was recorded for T2 (fertilizer application only). The treatments with biochar (T3, T4, and T5) showed lower soil EC values while soil only (T1) showed the lowest EC. The co-application of biochar tablet and NPK fertilizer (T4 and T3) significantly increased soil total C followed by T5, T1, and T2 (Table 3). Total $\mathrm{N}$ of soil only (T1) was the lowest followed by T2, T3, T5, and T4.

Table 3. Selected chemical properties of soil at 53 days after planting of sowing corn.

\begin{tabular}{cccccc}
\hline \multirow{2}{*}{ Chemical Properties } & \multicolumn{4}{c}{ Treatments } \\
\cline { 2 - 6 } & T1 & T2 & T3 & T4 \\
\hline EH & $5.59 \pm 0.05 \mathrm{a}$ & $4.81 \pm 0.03 \mathrm{~b}$ & $4.85 \pm 0.02 \mathrm{~b}$ & $4.95 \pm 0.04 \mathrm{~b}$ & $4.53 \pm 0.07 \mathrm{c}$ \\
Total $\mathrm{C}\left(\mathrm{g} \mathrm{kg}^{-1}\right)$ & $0.04 \pm 0.01 \mathrm{~d}$ & $0.38 \pm 0.01 \mathrm{a}$ & $0.32 \pm 0.01 \mathrm{~b}$ & $0.27 \pm 0.02 \mathrm{c}$ & $0.28 \pm 0.01 \mathrm{c}$ \\
Total N $\left(\mathrm{g} \mathrm{kg}^{-1}\right)$ & $7.90 \pm 0.20 \mathrm{c}$ & $7.80 \pm 0.20 \mathrm{c}$ & $40.20 \pm 1.01 \mathrm{a}$ & $44.80 \pm 0.76 \mathrm{a}$ & $28.83 \pm 2.45 \mathrm{~b}$ \\
Available P $\left(\mathrm{mg} \mathrm{kg}^{-1}\right)$ & $1.07 \pm 0.03 \mathrm{~d}$ & $1.43 \pm 0.03 \mathrm{c}$ & $1.90 \pm 0.06 \mathrm{~b}$ & $2.13 \pm 0.07 \mathrm{a}$ & $1.87 \pm 0.03 \mathrm{~b}$ \\
Exchangeable K $\left.\left(\mathrm{cmol}^{-1}\right) \mathrm{kg}^{-1}\right)$ & $0.24 \pm 0.04 \mathrm{e}$ & $50.58 \pm 0.64 \mathrm{c}$ & $70.31 \pm 1.43 \mathrm{a}$ & $54.75 \pm 0.96 \mathrm{~b}$ & $10.76 \pm 0.63 \mathrm{~d}$ \\
Exchangeable Ca $\left.\left(\mathrm{cmol}^{-1}\right) \mathrm{kg}^{-1}\right)$ & $7.17 \pm 1.15 \mathrm{a}$ & $7.50 \pm 0.33 \mathrm{a}$ & $7.41 \pm 0.04 \mathrm{a}$ & $7.66 \pm 0.70 \mathrm{a}$ & $5.73 \pm 0.05 \mathrm{a}$ \\
Exchangeable Mg $\left.\left(\mathrm{cmol}^{-1}\right) \mathrm{kg}^{-1}\right)$ & $0.69 \pm 0.09 \mathrm{a}$ & $0.58 \pm 0.02 \mathrm{a}$ & $0.55 \pm 0.01 \mathrm{a}$ & $0.63 \pm 0.08 \mathrm{a}$ & $0.50 \pm 0.01 \mathrm{a}$ \\
CEC $\left(\mathrm{cmol}(+) \mathrm{kg}^{-1}\right)$ & $11.08 \pm 1.33 \mathrm{a}$ & $12.94 \pm 1.45 \mathrm{a}$ & $11.59 \pm 0.83 \mathrm{a}$ & $13.11 \pm 1.08 \mathrm{a}$ & $11.78 \pm 0.52 \mathrm{a}$ \\
\hline
\end{tabular}

Values are means of three replicates followed by \pm standard error of means $(n=3)$. In each row, values with different letters differ significantly from each other at $p<0.05$.

Among the treatments, soil available P for T1 and T5 were lower compared with those of T2, T4, and T3. The soil with T3 improved exchangeable K compared with other treatments although total $\mathrm{K}$ use efficiency of sweet corn with T3 was lower than T5. The soil exchangeable $\mathrm{K}$ was low with $\mathrm{T} 1$ and T5. Nevertheless, no significant differences were recorded for the soil exchangeable $\mathrm{Ca}, \mathrm{Mg}$, and $\mathrm{CEC}$ among the treatments at $53 \mathrm{DAP}$.

\subsection{Biochar Tablets with and without Embedded Fertilizer on Leaf Chlorophyll Content}

Our study revealed that the plants which were treated with $\mathrm{T} 5$ demonstrated the highest leaf chlorophyll content. The leaf chlorophyll content of T1 was the highest followed by T4 (Figure 3). T1 showed the lowest leaf chlorophyll content while T2 and T3 showed no significant difference.

\subsection{Sweet Corn Plant Growth}

Table 4 shows the dry weight of the sweet corn plants at 53 days after planting. Soil only (T1) exhibited the lowest dry weight and nutrient use efficiency (leaves, stem, and roots) (Figure 4). The dry weight of leaves for T5 and T4 were significantly higher than those of T3, T2, and T1. A similar trend was observed for the dry weights of stem where T5 and T4 showed the highest values. The dry weight of stems for T1 was the lowest followed by $\mathrm{T} 2$ and $\mathrm{T} 3$. (Table 4 ) 


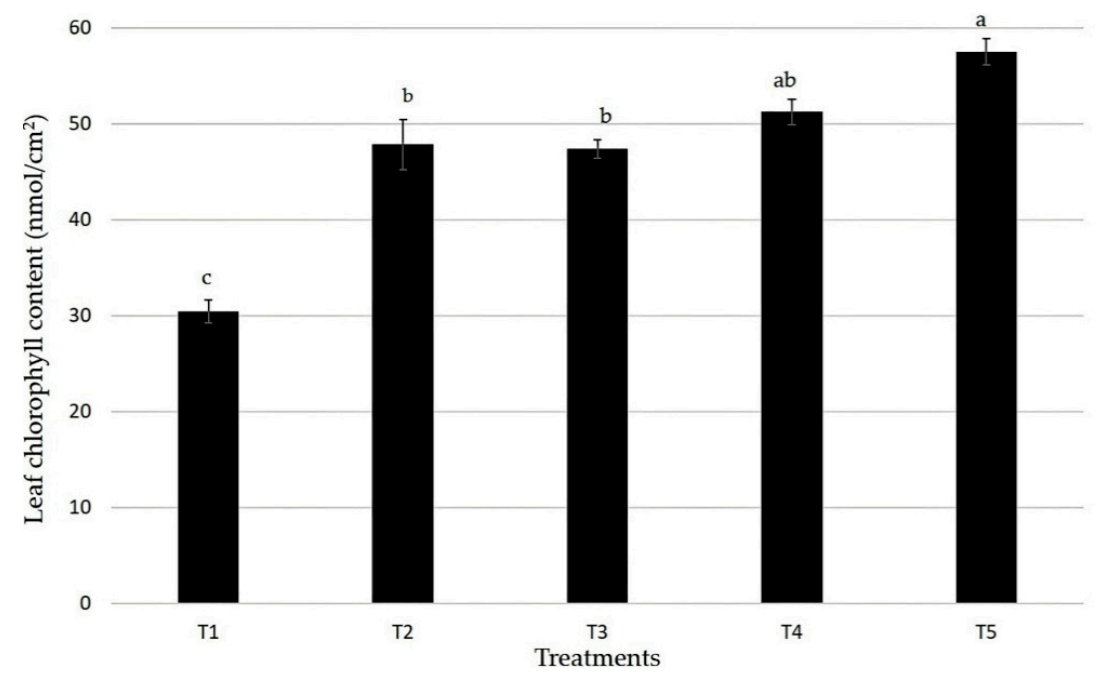

Figure 3. Effects of biochar tablets with and without embedded fertilizer on the leaves' chlorophyll contents. Bars represents values of five replicates and contain standard error of means $(n=5)$. Bars with different letters differ significantly from each other at $p<0.05$.

Table 4. Effects of treatments on dry weights of sweet corn plants at 53 days after planting.

\begin{tabular}{ccccc}
\hline \multirow{2}{*}{ Treatments } & Leaves & Stems & Roots & $\begin{array}{c}\text { Flowering } \\
\text { Tassels }\end{array}$ \\
\cline { 2 - 5 } & \multicolumn{4}{c}{$\mathbf{g}$} \\
\hline T1 & $3.59 \mathrm{c} \pm 0.13$ & $2.62 \mathrm{~d} \pm 0.14$ & $1.68 \mathrm{c} \pm 0.05$ & $\mathrm{n} . \mathrm{a}$ \\
$\mathrm{T} 2$ & $23.11 \mathrm{~b} \pm 0.53$ & $33.44 \mathrm{c} \pm 0.67$ & $13.31 \mathrm{~b} \pm 0.81$ & $5.30 \mathrm{~b} \pm 0.33$ \\
T3 & $23.14 \mathrm{~b} \pm 0.38$ & $40.27 \mathrm{~b} \pm 0.55$ & $14.08 \mathrm{~b} \pm 0.74$ & $9.01 \mathrm{a} \pm 0.52$ \\
T4 & $33.69 \mathrm{a} \pm 0.72$ & $57.66 \mathrm{a} \pm 2.03$ & $15.03 \mathrm{~b} \pm 0.22$ & $10.22 \mathrm{a} \pm 0.34$ \\
T5 & $33.94 \mathrm{a} \pm 1.70$ & $57.89 \mathrm{a} \pm 2.15$ & $24.66 \mathrm{a} \pm 0.48$ & $10.27 \mathrm{a} \pm 0.35$ \\
\hline
\end{tabular}

Values are means of three replicates followed by \pm standard error of means $(n=3)$. In each column, values with different letters differ significantly from each other at $p<0.05$.

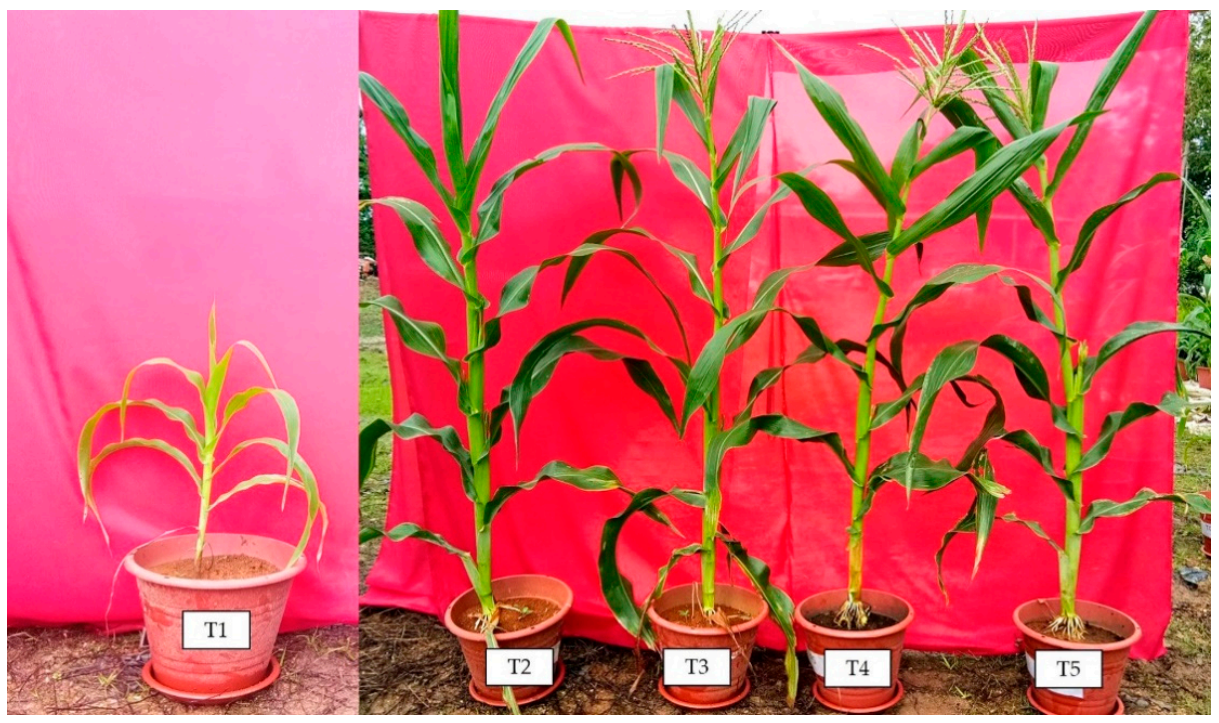

Figure 4. Sweet corn plant growth at 53 days after planting. T1: Soil only; T2: $36 \mathrm{~g}$ of mixture of NPK fertilizer; T3: $67 \mathrm{~g}$ (36 $\mathrm{g}$ of mixture NPK fertilizer + $31 \mathrm{~g}$ biochar tablet); T4: $67 \mathrm{~g}$ ( $29 \mathrm{~g}$ of mixture NPK fertilizer $+38 \mathrm{~g}$ biochar tablet); T5: $67 \mathrm{~g}$ of biochar tablet embedded fertilizer ( $23 \mathrm{~g}$ of NPK embedded $44 \mathrm{~g}$ of biochar tablet). 
Treatment T5 significantly increased the roots of the sweet corn compared with those for T4, T3, T2, and T1. The sweet corn plants without fertilizer (T1) did not tassel compared with those which were fertilized with NPK fertilizer (T2). Furthermore, the results demonstrated that the combination of biochar tablet and mineral fertilizer (T3, T4, and T5) significantly affected flowering tassels.

\subsection{Nutrients Uptake in Leaves, Stems, Roots, and Flowering Tassels of Sweet Corn}

The highest $\mathrm{N}$ uptake occurred in the sweet corn plant leaves and stems for T4 followed by T5, T3, T2, and T1. In comparison to other treatments, the lowest amount of fertilizer embedded in the biochar tablet (T5) increased N uptake by the sweet corn plant roots, whereas the $\mathrm{N}$ taken up by roots of the sweet corn plants with $\mathrm{T} 1$ was the lowest. Soil only could not significantly improve $\mathrm{N}$ uptake during flowering tassels because biochar and fertilizer were not used compared with $\mathrm{T} 5<\mathrm{T} 4<\mathrm{T} 3<\mathrm{T} 2$ which had biochar and NPK fertilizer.

Treatment 4 increased P uptake by the leaves of the sweet corn followed T2, T3, and T5. Treatment T1 had the lowest effect on P uptake by the stem of the sweet corn plants. The effects of T2, T3, T4, and T5 on P uptake by the stem of the sweet corn plants were similar (Table 5). The roots of T4 exhibited the lowest P uptake compared with T2, T3, and T5. At the tasseling stage of the sweet corn plants, the co-application of biochar and NPK fertilizer (T3, T4, and T5) significantly increased P uptake compared with NPK alone (T2).

Table 5. Nitrogen, phosphorus, and potassium uptake in leaves, stems, roots, and flowering tassels of sweet corn.

\begin{tabular}{|c|c|c|c|}
\hline \multirow{2}{*}{ Treatment } & \multicolumn{3}{|c|}{ Nutrients Uptake (mg/Plant) } \\
\hline & $\mathbf{N}$ & $\mathbf{P}$ & $\mathbf{K}$ \\
\hline \multicolumn{4}{|c|}{ Leaves } \\
\hline $\mathrm{T} 1$ & $59.00 \mathrm{~d}$ & $3.99 \mathrm{c}$ & $43.64 \mathrm{c}$ \\
\hline $\mathrm{T} 2$ & $623.97 c$ & $77.03 \mathrm{ab}$ & $363.75 \mathrm{~b}$ \\
\hline T3 & $624.78 \mathrm{c}$ & $67.03 \mathrm{~b}$ & $353.43 \mathrm{~b}$ \\
\hline $\mathrm{T} 4$ & 898.40 a & $86.13 \mathrm{a}$ & $502.09 \mathrm{a}$ \\
\hline $\mathrm{T} 5$ & $763.65 \mathrm{~b}$ & $68.56 \mathrm{~b}$ & $499.60 \mathrm{a}$ \\
\hline \multicolumn{4}{|c|}{ Stems } \\
\hline $\mathrm{T} 1$ & $31.27 \mathrm{e}$ & $4.23 \mathrm{~b}$ & $30.43 \mathrm{~d}$ \\
\hline $\mathrm{T} 2$ & $727.88 \mathrm{~d}$ & $76.35 \mathrm{a}$ & $543.96 \mathrm{c}$ \\
\hline T3 & $883.26 \mathrm{c}$ & $100.68 \mathrm{a}$ & $642.98 \mathrm{~b}$ \\
\hline $\mathrm{T} 4$ & $1226.24 \mathrm{a}$ & $125.70 \mathrm{a}$ & 891.81 a \\
\hline $\mathrm{T} 5$ & $1040.09 \mathrm{~b}$ & 81.43 a & $858.70 \mathrm{a}$ \\
\hline \multicolumn{4}{|c|}{ Roots } \\
\hline $\mathrm{T} 1$ & $12.54 \mathrm{~d}$ & $0.94 \mathrm{c}$ & $3.59 \mathrm{~d}$ \\
\hline $\mathrm{T} 2$ & $160.61 \mathrm{bc}$ & $13.98 \mathrm{a}$ & $83.94 \mathrm{a}$ \\
\hline T3 & $153.47 \mathrm{c}$ & $15.16 \mathrm{a}$ & $68.52 b$ \\
\hline $\mathrm{T} 4$ & $173.35 \mathrm{~b}$ & $11.47 \mathrm{~b}$ & $51.35 \mathrm{c}$ \\
\hline $\mathrm{T} 5$ & $238.38 \mathrm{a}$ & $15.21 \mathrm{a}$ & $56.97 \mathrm{c}$ \\
\hline \multicolumn{4}{|c|}{ Flowering Tassels } \\
\hline $\mathrm{T} 1$ & n.a & n.a & n.a \\
\hline $\mathrm{T} 2$ & $188.68 \mathrm{~d}$ & $23.00 \mathrm{~b}$ & $46.87 \mathrm{~b}$ \\
\hline T3 & $395.99 \mathrm{c}$ & $32.80 \mathrm{a}$ & $67.22 \mathrm{a}$ \\
\hline $\mathrm{T} 4$ & $461.43 \mathrm{~b}$ & $34.37 \mathrm{a}$ & $72.90 \mathrm{a}$ \\
\hline T5 & $496.04 \mathrm{a}$ & $37.04 \mathrm{a}$ & $76.92 \mathrm{a}$ \\
\hline
\end{tabular}

Values are means of three replicates followed by \pm standard error of means $(n=3)$. In each column, values with different letters differ significantly from each other at $p<0.05$.

The higher $\mathrm{K}$ uptake was observed in the leaves and stems caused by T4 and T5 whereas T2 (NPK fertilizer only) caused the highest K uptake in the roots of the sweet corn plants. The results revealed that T3, T4, and T5 significantly increased $\mathrm{K}$ uptake in flowering tassels in relative to T2 and T1. In comparison to treatments with biochar, higher 
K uptake by the aboveground biomass was observed in T3, T4, and T5 during the initiation of flowering tassels of sweet corn (Table 5).

3.5. Effects of Treatments on Nutrients Use Efficiency in Leaves, Stems, Roots, and Flowering Tassels of Sweet Corn

In this present study, the NPK fertilizer embedded with the biochar tablet (T5) significantly increased $\mathrm{N}, \mathrm{P}$, and $\mathrm{K}$ use efficiency in all of the parts of sweet corn plants (Tables 6 and 7). For T5 (biochar embedded with the lowest amount of NPK), the distribution the $\mathrm{N}$ use efficiency was in the order of: leaves, stem, roots, and flowering tassels of sweet corn. Additionally, the total N, P, and K uses efficiency of the sweet corn significantly increased with the biochar embedded with fertilizer (Table 7). On the contrary, the lower total N, P, and K uses efficiency were recorded for T2 that is, the treatment with fertilizer amendment only (Table 7). Overall, total N, P, K use efficiency of sweet corn caused by treatments followed the order: $\mathrm{T} 5>\mathrm{T} 4>\mathrm{T} 3>\mathrm{T} 2$.

Table 6. Nitrogen, phosphorus, and potassium use efficiency in leaves, stems, roots, and flowering tassels of sweet corn.

\begin{tabular}{|c|c|c|c|}
\hline \multirow{2}{*}{ Treatments } & \multicolumn{3}{|c|}{ Nutrients (\%) } \\
\hline & $\mathbf{N}$ & $\mathbf{P}$ & $\mathbf{K}$ \\
\hline \multicolumn{4}{|c|}{ Leaves } \\
\hline $\mathrm{T} 2$ & $2.35 \mathrm{c}$ & $1.04 \mathrm{~b}$ & $6.40 c$ \\
\hline T3 & $2.37 \mathrm{c}$ & $0.90 \mathrm{~b}$ & $6.19 c$ \\
\hline $\mathrm{T} 4$ & $4.35 \mathrm{~b}$ & $1.44 \mathrm{a}$ & $11.40 \mathrm{~b}$ \\
\hline $\mathrm{T} 5$ & $4.79 \mathrm{a}$ & $1.49 \mathrm{a}$ & $14.91 \mathrm{a}$ \\
\hline \multicolumn{4}{|c|}{ Stem } \\
\hline $\mathrm{T} 2$ & $2.90 \mathrm{~d}$ & $1.02 \mathrm{~b}$ & $10.27 \mathrm{~d}$ \\
\hline T3 & $3.55 c$ & $1.36 \mathrm{ab}$ & $12.25 \mathrm{c}$ \\
\hline $\mathrm{T} 4$ & $6.19 \mathrm{~b}$ & $2.18 \mathrm{a}$ & $21.38 \mathrm{~b}$ \\
\hline T5 & $6.86 \mathrm{a}$ & $1.83 \mathrm{ab}$ & $27.13 \mathrm{a}$ \\
\hline \multicolumn{4}{|c|}{ Roots } \\
\hline $\mathrm{T} 2$ & $0.62 c$ & $0.18 \mathrm{~b}$ & $1.61 \mathrm{a}$ \\
\hline $\mathrm{T} 3$ & $0.59 c$ & $0.20 \mathrm{~b}$ & $1.30 \mathrm{~b}$ \\
\hline $\mathrm{T} 4$ & $0.83 \mathrm{~b}$ & $0.20 \mathrm{~b}$ & $1.18 \mathrm{~b}$ \\
\hline $\mathrm{T} 5$ & $1.54 \mathrm{a}$ & $0.34 \mathrm{a}$ & $1.76 \mathrm{a}$ \\
\hline \multicolumn{4}{|c|}{ Flowering Tassels } \\
\hline $\mathrm{T} 2$ & $0.78 \mathrm{~d}$ & $0.33 \mathrm{~d}$ & $0.94 \mathrm{~d}$ \\
\hline T3 & $1.65 \mathrm{c}$ & $0.47 \mathrm{c}$ & $1.35 \mathrm{c}$ \\
\hline $\mathrm{T} 4$ & $2.36 \mathrm{~b}$ & $0.61 \mathrm{~b}$ & $1.81 \mathrm{~b}$ \\
\hline T5 & $3.37 \mathrm{a}$ & $0.87 \mathrm{a}$ & $2.51 \mathrm{a}$ \\
\hline
\end{tabular}

Values are means of three replicates followed by \pm standard error of means $(\mathrm{n}=3)$. In each column, values with different letters differ significantly from each other at $p<0.05$.

Table 7. Total nitrogen, phosphorus, and potassium use efficiency of sweet corn.

\begin{tabular}{cccc}
\hline \multirow{2}{*}{ Treatment } & \multicolumn{3}{c}{ Nutrients (\%) } \\
\cline { 2 - 4 } & $\mathbf{N}$ & $\mathbf{P}$ & $\mathbf{K}$ \\
\hline T2 & $6.66 \mathrm{~d}$ & $2.58 \mathrm{~b}$ & $19.22 \mathrm{~d}$ \\
T3 & $8.16 \mathrm{c}$ & $2.93 \mathrm{~b}$ & $21.09 \mathrm{c}$ \\
T4 & $13.74 \mathrm{~b}$ & $4.42 \mathrm{a}$ & $35.76 \mathrm{~b}$ \\
T5 & $16.56 \mathrm{a}$ & $4.53 \mathrm{a}$ & $46.32 \mathrm{a}$ \\
\hline
\end{tabular}

Values are means of three replicates followed by \pm standard error of means $(n=3)$. In each column, values with different letters differ significantly from each other at $p<0.05$.

\section{Discussion}

The constant input of chemical fertilizer in soil could adversely influence the soil quality. Biochar, a carbon rich solid organic material, has been suggested to improve 
soil $\mathrm{pH}$ and soil fertility [18]. In the present study, this light density of biochar was densified into tablet to ease for the handling and transportation. A high $\mathrm{pH}$ in BT was consistent with the $\mathrm{pH}$ of biochar obtained by Leng et al. [19], who also studied biochar production by combustion at low temperature and long residence time. Mixing NPK with the biochar decreased the $\mathrm{pH}$ of $\mathrm{BF}$, which was likely due to generation of sulfuric acids after the binding reactions between the oxygenated functional groups of biochar surfaces and ammonium sulfate [20]. Mixing NPK fertilizers created a very low $\mathrm{pH}$ and high EC in fertilizer microsite which could retard the plant growth. High mineral salts in NPK contributed to the high EC in BF. The EC value of BT fell in the range of biochar EC value reported by Limvikran et al. [21]. The highest total nutrients found in NPK was correlated with the soluble fertilizer sources. Therefore, blending of fertilizer with the BF led to higher concentration of total nitrogen, phosphorus, and potassium relative to BT. It is essential for the BFs to contain ample amounts of essential plant nutrients, which could supplement the sole biochar application or conventional fertilizers.

The $\mathrm{pH}$ of soil used in this study falls in the range of Oxisol soil reported by Ndzana et al. [22] and it is ideal for corn plant growth [23]. The results were in consensus with Shibata et al. [24] who also reported that Oxisol soil has low total C and N. It appears that soil available P was very low to meet the plant demand [25]. Similarly, low content of exchangeable $\mathrm{K}, \mathrm{Ca}, \mathrm{Mg}$, and $\mathrm{CEC}$ were found in the soil before sweet corn planting. The soil CEC of this study falls in the range of CEC compiled in Oxisol soil by $\mathrm{Xu}$ et al. [26]. The data in Table 2 indicates the soil used in the pot experiment was infertile and additional nutrients were needed for a healthy plant growth.

Application of NPK fertilizer and biochar (T2, T3, T4, and T5) significantly decreased the soil $\mathrm{pH}$ and this finding is inconsistent with that of Oladele et al. [2] who reported an increase in soil $\mathrm{pH}$ using biochar. The decrease in the soil $\mathrm{pH}$ is related to the ammonium sulfate used in this present study because it might have released the hydrogen ions during nitrification because this chemical reaction deceases soil $\mathrm{pH}$ [27]. The soil $\mathrm{pH}$ for T5 suggests the role of fertilizer embedded in biochar tablet improved soil microbial activities, accelerated nitrification rates, and ammonium uptake by the sweet corn plants such that these processes led to soil acidification. High application rate of biochar favors nitrification. High application rate of biochar which specifically favors the nitrification activity of microbes has also been reported by He et al. [28]. The higher EC for T2 (fertilizer application only) is typical of NPK fertilizers because of their mineral salts content. The treatments with biochar (T3, T4, and T5) showed lower soil EC values because the adsorption sites of the biochar reacted with the soluble salts for a new equilibrium. Among the treatments, soil only (T1) showed the lowest EC because of lower salts.

The co-application of biochar tablet and NPK fertilizer (T4 and T3) significantly increased soil total $C$ because of the inherent content of $C$ in the biochar tablet (Table 1). Dong et al. [29] also reported increase in soil $C$ with increasing biochar application. On the contrary, the biochar tablet embedded fertilizer application (T5) demonstrated lower soil total C. This is because the oxidized compounds on the surface of the biochar tablet embedded with fertilizer (T5) which reacted with mineral fertilizer might have shifted the non-labile $C$ compounds to more labile $C$ compounds [30] followed by them being decomposed by the soil microorganisms. The highest soil total $\mathrm{N}$ in T4 was due to the higher amount of the biochar in the biochar tablets $(38 \mathrm{~g})$. This observation agrees with the findings of Thangarajan et al. [31] who also reported that high amount of biochar increases sorption of $\mathrm{N}$ on biochar surfaces in the soil compared $\mathrm{N}$ fertilizer only. Nitrogen use without amendments such as biochar does not prevent, for example, ammonium from being leached from soils particularly during rainfall.

The lower available P of T1 was due to no P fertilizer application whereas that for T5 was because the applied P was efficiently taken up (this treatment demonstrated the highest $P$ use efficiency) and utilized by the sweet corn plants for growth and development. Moreover, the fact that $\mathrm{T} 5 \mathrm{had}$ the highest effect on the dry weight of the sweet corn roots suggests the viability of the roots of this crop played a significant role in the improved 
productivity of the sweet corn plants. Although the highest soil available P was observed in T3, total P use efficiency of the sweet corn with this treatment was lower compared with those with T4 and T5 due to the high EC associated with T3. High soil EC hinders nutrient uptake because it increases osmotic pressure of the soil nutrient solution [32].

The total K use efficiency of T3 was similar to the total P use efficiency, suggesting that unbalanced use of fertilizers can increase stress of plants to a level that could limit them from taking nutrients efficiently. Nevertheless, no significant differences were recorded for the soil exchangeable $\mathrm{Ca}, \mathrm{Mg}$, and CEC among the treatments at 53 DAP. These findings contrasted those of Jien and Wang [33] and Wang et al. [34] who reported increase in soil $\mathrm{CEC}$, exchangeable $\mathrm{Ca}$, and $\mathrm{K}$ following application of biochar to the acidic alfisols soil. In this present study, densification of fine biochar particles which caused reduction in the surface area and porous characteristics of the biochar explains why this amendment could not significantly increase soil CEC, exchangeable $\mathrm{Ca}$, and $\mathrm{Mg}$.

Allen Dray Jr et al. [35] reported a strong relationship between leaf chlorophyll content and tissue $\mathrm{N}$ levels of plants. The plants which were treated with $\mathrm{T} 5$ demonstrated the highest leaf chlorophyll content suggesting higher photosynthesis [36]. Additionally, it adds credence to the ability of the biochar tablet with embedded fertilizer to increase $\mathrm{N}$ uptake by plant and concentration of photosynthetic pigments in leaves to the extent that these effects translated into higher biomass production in T5. The leaves chlorophyll contents for T1, T2, T3, and T4 were within the range reported by Yuan et al. [37]. There was no additional fertilizer and biochar explaining T1 had the lowest dry weight and nutrient use efficiency (leaves, stem, and roots). A lower dry weight of plants was observed in T2 which indicates the high mineral salts deposit to soil can impede crop growth and development through osmotic and specific ion stresses in addition reducing nutrient uptake [38]. Conversely, the amount of NPK fertilizer that was reduced in T4 and T5 showed better dry weight of leaves and stems among the treatments. This was possibly due to a higher biochar rate increasing the adsorption sites of the biochar reacted with the soluble salts in soils towards a new equilibrium [39] and thereby reduced the effect of fertilizer on the soil salinity. The ability of the biochar tablets to reduce salinity of the soluble mineral salts released by the NPK fertilizer explains the lower values of the EC of the soils with T4 and T5. In addition, treatment T5 significantly increased the roots of the sweet corn. This observation is comparable to that of Cao et al. [40], who also reported highest root activity when $\mathrm{N}$ fertilizer was applied at a lower levels in a biochar-amended soil. It was apparent that the sweet corn plants got stunted out of insufficient nutrient supply in T1. Furthermore, the combination of biochar tablet and mineral fertilizer (T3, T4, and T5) significantly affected flowering tasseling. This was possible because the biochar stimulated microbial activity in addition to releasing the nutrients in the biochar tablets slowly for timely uptake by the sweet corn plants [41]. Additionally, the high $\mathrm{K}$ of the biochar (ash produced during pyrolysis) accelerated flowering of the tassel inflorescences [42]. Pandit et al. [43] also reported increased $\mathrm{K}$ upon biochar addition to soil increased maize grain yield.

The nutrient uptake of the sweet corn plants without fertilization was poor because nutrient deficiency stunted plants. The highest $\mathrm{N}$ uptake occurred in the sweet corn plant leaves and stems for T4 followed by T5, T3, T2, and T1. This indicates that optimum biochar tablet application improved soil total $\mathrm{N}$ and this resulted in the improved $\mathrm{N}$ uptake in the leaves and stems of plants [40]. High doses of biochar tablets significantly increased the soil total $\mathrm{N}$ in T4 (Table 3) and this increased the $\mathrm{N}$ uptake of leaves and stems. The possible reason is that high doses of biochar increased more surface functional groups to retain ammonium for soil $\mathrm{N}$ improvement [44].

In comparison to other treatments, the lowest amount of fertilizer embedded in the biochar tablet (T5) increased $\mathrm{N}$ uptake by the sweet corn plant roots, suggesting that biochar densification with low amounts of fertilizer is an effective means of reducing the inhibition effect of high $\mathrm{N}$ on plant root viability. Soil only could not significantly improve $\mathrm{N}$ uptake during flowering tassels because biochar and fertilizer were not used. Treatment 
T5 significantly increased $\mathrm{N}$ uptake during the tasseling stage, it enhanced rapid flower initiation because sufficient amount of $\mathrm{N}$ was used for the sweet corn plant reproductive structure. The reduction in $\mathrm{N}$ uptake by leaves and stems of the sweet corn plant which received T5 was due to allocation of a significant amount $\mathrm{N}$ for the reproductive structures during the reproductive period [45].

Treatment 4 increased P uptake by the leaves of the sweet corn followed T2, T3, and T5. The highest $\mathrm{N}$ uptake was also observed in the leaves of T4 (Table 5). These findings are consistent with those of Razaq et al. [46] and Long et al. [47] who also reported that $\mathrm{N}$ promotes $\mathrm{P}$ in plant uptake by increasing the aboveground biomass growth of plants. The roots of T4 exhibited the lowest $P$ uptake compared with T2, T3, and T5. High accumulation of $\mathrm{P}$ in the leaves might have slowed down the $\mathrm{P}$ uptake by the roots with $\mathrm{T} 4$ as energized transport of $\mathrm{P}$ from soil to plant is responsive to the $\mathrm{P}$ starvation in the plants [48]. At the tasseling stage of the sweet corn plants, the co-application of biochar and NPK fertilizer (T3, T4, and T5) significantly increased P uptake compared with NPK alone (T2) partly because the high $\mathrm{K}$ of the biochar might have accelerated tasseling [41]. The higher $\mathrm{K}$ in the leaves and stems caused by T4 and T5 indicates that co-application of optimum amount of biochar and NPK improves K uptake in the leaves and stems of the sweet corn plants. Although biochar tablets improve soil K availability [49], in this present study, T2 (NPK fertilizer only) caused the highest $\mathrm{K}$ uptake in the roots of the sweet corn plants. Potassium uptake by roots mainly depends on the growth rate of plants. High allocation of $\mathrm{K}$ in the roots of T2 could be ascribed to sustain the life cycle of the plant. In comparison to treatments with biochar, higher $\mathrm{K}$ uptake by the aboveground biomass was observed in T3, $\mathrm{T} 4$, and T5 during the initiation of flowering tassels of sweet corn (Table 5). Therefore, high $\mathrm{K}$ allocation in the roots of $\mathrm{T} 2$ indicates that a slow $\mathrm{K}$ translocation to the vegetative and reproductive parts would slow down the development of new tissues and ears. This result explains the lowest $\mathrm{K}$ uptake in flowering tassels of $\mathrm{T} 2$.

Low nutrient use efficiency (NUE) of inorganic fertilizers does not only cause low crop yield but it also increases production cost and environmental pollution. Therefore, improving the efficiency of fertilizer use is of utmost importance for developing sustainable agriculture. In this present study, the NPK fertilizer embedded with the biochar tablet (T5) significantly increased N, P, and K use efficiency in all of the parts of sweet corn plants (Tables 6 and 7). These findings suggest the potential of the biochar tablets embedded with fertilizer to increase sweet corn plants productivity. On the contrary, the lower total N, P, and $\mathrm{K}$ uses efficiency were recorded for $\mathrm{T} 2$ that is, the treatment with fertilizer amendment only and this could be attributed to the EC of T2 as earlier discussed that it impeded the growth and development of the roots of the sweet corn plants.

\section{Conclusions}

Co-application of biochar and fertilizer increases soil total carbon, nitrogen, but reduced soil EC. The BF significantly increased leaf chlorophyll content, dry root weight, and total plant nutrient use efficiency of sweet corn. Fertilizer only had the lowest effect on the total nutrient uptake efficiency of sweet corn. The findings suggest that BF can serve as a slow release fertilizer not only to improve nutrient use efficiency that improves soil and crop productivity but it will also reduce leaching of nutrients into water bodies to cause for example, eutrophication. Therefore, embedding fertilizer in biochar tablets is recommended for sweet corn production following a long term field study to confirm the findings of this pot study.

Author Contributions: Conceptualization, Y.L.L. and O.H.A.; methodology, Y.L.L. and S.A.W.; investigation, Y.L.L.; resources, Y.L.L. and Z.F.A.A.; writing—original draft preparation, Y.L.L.; writing-review and editing, O.H.A. and S.A.W.; visualization, Z.F.A.A.; supervision, O.H.A., S.A.W. and Z.F.A.A.; project administration, Y.L.L.; funding acquisition, O.H.A. All authors have read and agreed to the published version of the manuscript. 
Funding: This research was funded by Ministry of Higher Education, Malaysia with grant number [ERGS/1/11/STWN/UPM/02/65] and the APC was funded by Universiti Putra Malaysia.

Institutional Review Board Statement: Not applicable.

Informed Consent Statement: Not applicable.

Data Availability Statement: Data are available from the author.

Acknowledgments: The authors would like to acknowledge the Ministry of Higher Education, Malaysia for funding this research project through the Exploratory Research Grant Scheme (ERGS) grant code ERGS/1/11/STWN/UPM/02/65. Also, we acknowledge Universiti Putra Malaysia for the collaborative research.

Conflicts of Interest: The authors declare no conflict of interest.

\section{References}

1. Muller, J. Production of Fertilizer in Malaysia 2013-2019; Statista: Hamburg, Germany, 2020.

2. Oladele, S.; Adeyemo, A.; Awodun, M.; Ajayi, A.; Fasina, A. Effects of biochar and nitrogen fertilizer on soil physicochemical properties, nitrogen use efficiency and upland rice (Oryza sativa) yield grown on an Alfisol in Southwestern Nigeria. Int. J. Recycl. Org. Waste Agric. 2019, 8, 295-308. [CrossRef]

3. Lima, J.R.D.S.; Silva, W.D.M.; Medeiros, E.V.D.; Duda, G.P.; Corrêa, M.M.; Filho, A.P.M.; Clermont-Dauphin, C.; Antonino, A.C.; Hammecker, C. Effect of biochar on physicochemical properties of a sandy soil and maize growth in a greenhouse experiment. Geoderma 2018, 319, 14-23. [CrossRef]

4. Sadaf, J.; Shah, G.A.; Shahzad, K.; Ali, N.; Shahid, M.; Ali, S.; Hussain, R.A.; Ahmed, Z.I.; Traore, B.I.; Ismail, M.I.; et al. Improvements in wheat productivity and soil quality can accomplish by co-application of biochars and chemical fertilizers. Sci. Total Environ. 2017, 607, 715-724. [CrossRef]

5. Tang, L.; Yu, J.; Pang, Y.; Zeng, G.; Deng, Y.; Wang, J.; Ren, X.; Ye, S.; Peng, B.; Feng, H. Sustainable efficient adsorbent: Alkali-acid modified magnetic biochar derived from sewage sludge for aqueous organic contaminant removal. Chem. Eng. J. 2018, 336, 160-169. [CrossRef]

6. Guilhen, S.N.; Masek, O.; Ortiz, N.; Izidoro, J.C.; Fungaro, D.A. Pyrolytic temperature evaluation of macauba biochar for uranium adsorption from aqueous solutions. Biomass Bioenerg. 2019, 122, 381-390. [CrossRef]

7. Angin, D.; Sensoz, S. Effect of Pyrolysis Temperature on Chemical and Surface Properties of Biochar of Rapeseed (Brassica napus L.). Int. J. Phytoremediat. 2014, 16, 684-693. [CrossRef]

8. Guerena, D.; Lehmann, J.; Hanley, K.; Enders, A.; Hyland, C.; Riha, S. Nitrogen dynamics following field application of biochar in a temperate North American maize-based production system. Plant Soil. 2013, 365, 239-254. [CrossRef]

9. Sun, H.; Min, J.; Zhang, H.; Feng, Y.; Lu, K.; Shi, W.; Yu, M.; Li, X. Biochar application mode influences nitrogen leaching and $\mathrm{NH}_{3}$ volatilization losses in a rice paddy soil irrigated with N-rich wastewater. Environ. Technol. 2018, 39, 2090-2096. [CrossRef]

10. Teutscherova, N.; Houska, J.; Navas, M.; Masaguer, A.; Benito, M.; Vazquez, E. Leaching of ammonium and nitrate from Acrisol and Calcisol amended with holm oak biochar: A column study. Geoderma 2018, 323, 136-145. [CrossRef]

11. Husk, B.; Major, J. Commercial Scale Agricultural Biochar Field Trial in Quebec, Canada, Over Two Years: Effects of Biochar on Soil Fertility, Biology, Crop Productivity and Quality; Blue Leaf: Quebac, QC, Canada, 2008; pp. 1-38.

12. Kim, P.; Hensley, D.; Labbe, N. Nutrient release from switchgrass-derived biochar pellets embedded with fertilizers. Geoderma 2014, 232-234, 341-351. [CrossRef]

13. Lee, Y.L.; Ahmed, O.H.; Wahid, S.A.; AB Aziz, Z.F. Effects of Mixture Biochar-Fertilizer with and without Tableting on the Soil Chemical Characteristics. IOP Conf. Ser. Mater. Sci. Eng. 2020, 864, 012100. [CrossRef]

14. Muramoto, J.; Goto, I.; Ninaki, M. Application of inductively coupled atomic emission spectroscopy to soil analysis. Part. 6. Rapid analysis of exchangeable cations and cation exchange capacity by a shaking extraction method. Jpn. J. Soil Sci. Plant Nutr. 1992, 63, 210-218.

15. Bray, R.H.; Kurtz, L. Determination of total, organic, and available forms of phosphorus in soils. Soil Sci. 1945, 59, 39-46. [CrossRef]

16. Cottenie, A. Soil testing and plant testing as a basis of fertilizer recommendation. FAO Soil Bull. 1980, 38, 3-70.

17. Pomares-Gracia, F.; Pratt, P.F. Recovery of $15 \mathrm{~N}-$ labelled fertilizer from manured and sludge-amended soils. Soil Sci. Soc. Am. J. 1987, 42, 717-720. [CrossRef]

18. Yu, H.; Zou, W.; Chen, J.; Chen, H.; Yu, Z.; Huang, J.; Tang, H.; Wei, X.; Gao, B. Biochar amendment improves crop production in problem soils: A review. J. Environ. Manag. 2019, 232, 8-21. [CrossRef]

19. Leng, L.Y.; Husni, M.H.A.; Samsuri, A.W. Comparison of the carbon-sequestering abilities of pineapple leaf residue chars produced by controlled combustion and by field burning. Bioresour. Technol. 2011, 102, 10759-10762. [CrossRef] [PubMed]

20. Xue, B.; Huang, H.; Mao, M.; Liu, E. An investigation of the effect of ammonium sulfate addition on compound fertilizer granulation. Particuology 2017, 31, 54-58. [CrossRef] 
21. Limvikran, T.; Kheoruenromne, I.; Suddhiprakarn, A.; Prakongkep, N.; Gilkes, R.J. Dissolution of K, Ca, and P from biochar grains in tropical soils. Geoderma 2018, 312, 139-150. [CrossRef]

22. Ndzana, G.M.; Huang, L.; Zhang, Z.; Zhu, J.; Liu, F.; Bhattacharyya, R. The transformation of clay minerals in the particle size fractions of two soils from different latitude in China. Catena 2019, 175, 317-328. [CrossRef]

23. Mallarino, A.P. Corn and soybean response to soil $\mathrm{pH}$ level and liming. In Integrated Crop Management Conference; Iowa State University: Ames, IA, USA, 2011; pp. 93-102. [CrossRef]

24. Shibata, M.; Sugihara, S.; Mvondo-Ze, A.D.; Araki, S.; Funakawa, S. Nitrogen flux patterns through Oxisols and Ultisols in tropical forests of Cameroon, Central Africa. Soil Sci. Plant Nutr. 2017, 63, 306-317. [CrossRef]

25. El-Ramady, H.R.; Alshaal, T.A.; Amer, M.; Domokos-Szabolcsy, E.; Elhawat, N.; Prokisch, J.; Fari, M. Soil Quality and Plant Nutrition. Sustain. Agric. Rev. 2014, 14, 345-447. [CrossRef]

26. Xu, R.; Zhao, A.; Yuan, J.; Jiang, J. pH buffering capacity of acid soils from tropical and subtropical regions of China as influenced by incorporation of crop straw biochars. J. Soil. Sediment. 2012, 12, 494-502. [CrossRef]

27. Fageria, N.K.; Santos, A.B.D.; Moraes, M.F. Influence of Urea and Ammonium Sulfate on Soil Acidity Indices in Lowland Rice Production. Commun. Soil Sci. Plan. 2010, 41, 1565-1575. [CrossRef]

28. He, L.; Zhao, H.; Wang, S.; Xing, G. The effects of rice-straw biochar addition on nitrification activity and nitrous oxide emissions in two Oxisols. Soil Till. Res. 2016, 164, 52-62. [CrossRef]

29. Dong, X.; Singh, B.P.; Li, G.; Lin, Q.M.; Zhao, X. Biochar increased field soil inorganic carbon content five years after application. Soil Till. Res. 2019, 186, 36-41. [CrossRef]

30. Lee, Y.L.; Ahmed, O.H.; Wahid, S.A.; AB Aziz, Z.F. Characterization of tablets made from mixture of charred agricultural residues with and without embedded fertilizer. Acta Technol. Agric. 2019, 22, 70-74. [CrossRef]

31. Thangarajan, R.; Bolan, N.S.; Kunhikrishnan, A.; Wijesekara, H.; Xu, Y.; Tsang, D.C.; Song, H.; Ok, Y.S.; Hou, D. The potential value of biochar in the mitigation of gaseous emission of nitrogen. Sci. Total Environ. 2018, 612, 257-268. [CrossRef]

32. Ding, X.; Jiang, Y.; Zhao, H.; Guo, D.; He, L.; Liu, F.; Zhou, Q.; Nandwani, D.; Hui, D.; Yu, J. Electrical conductivity of nutrient solution influenced photosynthesis, quality, and antioxidant enzyme activity of pakchoi (Brassica campestris L. ssp. Chinensis) in a hydroponic system. PLoS ONE 2018, 13, e0202090. [CrossRef] [PubMed]

33. Jien, S.; Wang, C. Effects of biochar on soil properties and erosion potential in a highly weathered soil. Catena 2013, 110, 225-233. [CrossRef]

34. Wang, Y.; Yin, R.; Liu, R. Characterization of biochar from fast pyrolysis and its effect on chemical properties of the tea garden soil. J. Anal. Appl. Pyrolysis 2014, 110, 375-381. [CrossRef]

35. Allen Dray, F., Jr.; Center, T.D.; Mattison, E.D. In situ estimates of waterhyacinth leaf tissue nitrogen using a SPAD-502 chlorophyll meter. Aquat. Bot. 2012, 100, 72-75. [CrossRef]

36. Martin, A.; Belastegui-Macadam, X.; Quillere, I.; Floriot, M.; Valadier, M.H.; Pommel, B.; Andrieu, B.; Donnison, I.; Hirel, B. Nitrogen management and senescence in two maize hybrids differing in the persistence of leaf greenness: Agronomic, physiological and molecular aspects. New Phytol. 2005, 167, 483-492. [CrossRef] [PubMed]

37. Yuan, Z.; Ata-Ul-Karim, S.T.; Cao, Q.; Lu, Z.; Cao, W.; Zhu, Y.; Liu, X. Indicators for diagnosing nitrogen status of rice based on chlorophyll meter readings. Field Crops Res. 2016, 185, 12-20. [CrossRef]

38. Huang, L.; Liu, X.; Wang, Z.; Liang, Z.; Wang, M.; Liu, M.; Suarez, D.L. Interactive effects of pH, EC and nitrogen on yields and nutrient absorption of rice (Oryza sativa L.). Agric. Water Manag. 2017, 194, 48-57. [CrossRef]

39. De Vasconcelos, A.C.F. Biochar Effects on Amelioration of Adverse Salinity Effects in Soils. In Applications of Biochar for Environmental Safety; Abdelhafez, A.A., Abbas, M.H.H., Eds.; IntechOpen: London, UK, 2020. [CrossRef]

40. Cao, H.; Ning, L.; Xun, M.; Feng, F.; Li, P.; Yue, S.; Song, J.; Zhang, W.; Yang, H. Biochar can increase nitrogen use efficiency of Malus hupehensis by modulating nitrate reduction of soil and root. Appl. Soil Ecol. 2019, 135, 25-32. [CrossRef]

41. Bass, A.M.; Bird, M.I.; Kay, G.; Muirhead, B. Soil properties, greenhouse gas emissions and crop yield under compost, biochar and co-composted biochar in two tropical agronomic systems. Sci. Total Environ. 2016, 550, 459-470. [CrossRef] [PubMed]

42. Zeb, N. Effect of Potassium and Maleic Hydrazide on Growth and Flower Quality of Chrysanthemum (Dendranthema grandiflorum). Sarhad J. Agric. 2015, 31, 210-216. [CrossRef]

43. Pandit, N.R.; Mulder, J.; Hale, S.E.; Martinsen, V.; Schmidt, H.P.; Cornelissen, G. Biochar improves maize growth by alleviation of nutrient stress in a moderately acidic low-input Nepalese soil. Sci. Total Environ. 2018, 625, 1380-1389. [CrossRef]

44. Sohi, S.; Capel, E.L.; Krull, E.; Bol, R. Biochar, climate change and soil: A review to guide future research. In CSIRO Land Water Science Report; Collingwood: Victoria, Australia, 2010; pp. 1-64.

45. Rentsch, D.; Schmidt, S.; Tegeder, M. Transporters for uptake and allocation of organic nitrogen compounds in plants. FEBS Lett. 2007, 581, 2281-2289. [CrossRef]

46. Razaq, M.; Zhang, P.; Shen, H.; Salahuddin. Influence of nitrogen and phosphorous on the growth and root morphology of Acer mono. PLoS ONE 2017, 12, e0171321. [CrossRef] [PubMed]

47. Long, M.; Wu, H.H.; Smith, M.D.; La Pierre, K.J.; Lu, X.; Zhang, H.; Han, X.; Yu, Q. Nitrogen deposition promotes phosphorus uptake of plants in a semi-arid temperate grassland. Plant Soil. 2016, 408, 475-484. [CrossRef]

48. Schachtman, D.P.; Reid, R.J.; Ayling, S.M. Phosphorus Uptake by Plants: From Soil to Cell. Plant Physiol. 1998, 116, 447-453. [CrossRef] [PubMed] 
49. Wang, L.; Xue, C.; Nie, X.; Liu, Y.; Chen, F. Effects of biochar application on soil potassium dynamics and crop uptake. J. Plant Nutr. Soil Sci. 2018, 181, 635-643. [CrossRef] 